- CCS projects in other nations.

GreenGen was originally seen as a follow-up to FutureGen, the flagship US initiative that was promoted and then cancelled by former president George W. Bush. In 2009, President Barack Obama revived the project, but a business consortium has yet to settle on a home for it. Many are sceptical about whether FutureGen and other US CCS projects will come to fruition, given the inability of Congress to craft a comprehensive programme for reducing greenhouse-gas emissions.

The United Kingdom is also trying to renew interest in CCS. On 3 April, the UK Department of Energy and Climate Change relaunched a $£ 1$-billion (US\$1.6-billion) competition for companies to build CCS demonstration plants. An earlier initiative, launched in 2007, fell apart in 2011 when the last remaining consortium pulled out because of concerns over costs. This time, the UK government has encouraged companies by promising that electricity produced by CCS plants can be sold at premium prices, and it will also provide $£ 125$ million for CCS research and development.

Many countries still see potential CCS plants as one-off demonstration projects, but the United Kingdom is trying to create conditions for them to become commercially viable, says Stuart Haszeldine, a geologist working on CCS at the University of Edinburgh, UK. So far, seven consortia have publicly announced their interest in the contest, which aims to commission plants in 2016-20 and store carbon dioxide in porous rock under the North Sea.

Other well-advanced initiatives include Canada's Boundary Dam Integrated Carbon Capture and Storage Demonstration Project in Saskatchewan, a 100-megawatt project to retrofit carbon-capture technology to an existing power plant; and the Texas Clean Energy Project, a 400-megawatt integrated gasification combined-cycle plant that could begin operating in 2014. Both plan to sell carbon dioxide to oil companies, which use the gas to flush oil out of reservoirs. In the Netherlands, the Rotterdam Capture and Storage Demonstration project aims to begin storing carbon dioxide in depleted gas fields under the North Sea in 2015.

Howard Herzog, a carbon-storage expert at the Massachusetts Institute of Technology in Cambridge, says that the challenge facing the entire carboncapture industry is how to turn a profit in the absence of a serious carbon policy that rewards emissions-reduction projects financially. "The question is whether there

$\rightarrow$ NATURE.COM

For more about

GreenGen, see:

go.nature.com/2cmgm5 is a CCS market anywhere in the world," Herzog says. "If there isn't, why develop the technology?"

\title{
Roche chases stake in medical sequencing
}

\author{
Biotech firm Illumina continues to resist takeover - but \\ analysts suggest that a merger is inevitable.
}

\section{BY ERIKA CHECK HAYDEN}

$\mathrm{G}$ ene sequencing has mainly been the province of technology companies catering to researchers, but the pharmaceutical giant Roche, based in Basel, Switzerland, has other plans. It is increasing the pressure on Illumina, a DNA-sequencing company headquartered in San Diego, California, hoping to absorb the firm and use its expertise to capture the growing market in personalized medicine.

Roche proposed a merger in January, offering US $\$ 44.50$ per share, which Illumina's board rejected. On 29 March, Roche raised its bid to $\$ 51$ per share, for a total acquisition price of $\$ 6.7$ billion. Illumina's board rejected this offer, too, and adopted a 'poison-pill' provision that would give present investors the right to buy new shares at a reduced price, thereby diluting the value of Roche's shares if the deal goes through. But many observers say that the merger is all but certain. "If Roche really wants this, they are ultimately going to be able to make this go through," says John Haggerty, a mergers-and-acquisitions lawyer with Goodwin Procter in Boston, Massachusetts.

Roche's interest in Illumina stems from the latter's dominant position in genetic research; it claims that $90 \%$ of the world's sequencing is done on its machines. Roche believes that whole-genome sequencing is poised to become a lucrative diagnostic tool, and that Illumina will allow it to break into that market.

Illumina could benefit from Roche's vast sales

\section{DOWN AND UP}

Illumina's share price fell last year owing to gloom over biomedical-research funding. Roche's January bid boosted it, but only part way.

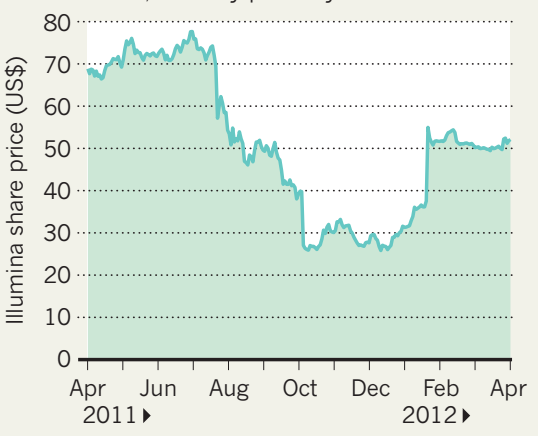

force, which would make it more competitive with its major rival, Life Technologies of Carlsbad, California. And Roche's experience in diagnostics and drug development could speed the translation of sequencing into the clinic, says David Ferreiro, a Boston-based analyst at the investment bank Oppenheimer. Manufacturers are eager to move from next-generation sequencing technology into diagnostic technology, and "Roche could do that a lot faster" than Illumina could, he says.

Yet Illumina has fought back, arguing to its shareholders that Roche's offer undervalues the company (see 'Down and up'). Illumina, which started out in the 1990s as a microarray vendor, came to dominate the sequencing market by steadily cutting the cost and improving the speed and ease of use of its products.

However, Illumina now has numerous competitors with new platforms nipping at its heels. The firm is cagey about what technologies could replace its current sequencing machines, even as the newcomers, such as Oxford Nanopore Technologies in Oxford, UK, are promising big leaps in the speed and price of sequencing - with the aim of attaining the $\$ 1,000$ human genome. Industry observers question whether Illumina's nimbleness will survive a Roche merger. They point to Roche's 2007 acquisition of sequencing company 454 Life Sciences in Branford, Connecticut, which has since failed to live up to hopes that it would capture a significant part of the market.

To up the pressure, Roche has nominated six people for Illumina's board of directors who, if elected by shareholders at the company's annual meeting on 18 April, might coax the board to work out a deal. But with advisory firms cautioning major shareholders to hold out, Roche will probably continue to raise its price to entice institutional investors and arbitrage traders, who bought Illumina shares expecting Roche to sweeten its offer. "It's just a matter of how much the Illumina board can force them into raising their price before the stockholders start accepting the offer," says Haggerty.

For Illumina, the end could be bittersweet. The company may be in a prime position to dominate the potentially lucrative clinicalsequencing market. But it may also see the end of its glory days as a key innovator in sequencing.. 